\title{
PARTICIPATION IN MULTILATERAL TREATIES
}

\section{Editorial introduction}

This section records the participation of Asian states in open multilateral law-making treaties which mostly aim at world-wide adherence. It updates the treaty sections of earlier Volumes until 31 December 2002. New data are preceded by a reference to the most recent previous entry. In case no new data are available, the title of the treaty will be listed with a reference to the latest Volume containing such data.

For the purpose of this section states situated broadly west of Iran, north of Mongolia, east of Papua New Guinea and south of Indonesia will not be covered. The Editors wish to express their gratitude to all international organizations that have so kindly made available information on the status of various categories of treaties.

Note:

- Where no other reference to specific sources is made, data are derived from Multilateral Treaties deposited with the Secretary-General - Status as at 31 December 2002 (ST/LEG/SER.E/21).

- No indication is given of reservations and declarations made.

- $\quad$ Sig. = signature; Cons. = consent to be bound; Eff. date = effective date; E.i.f. = entry into force; Ratif. registered $=$ ratification registered; Min. age spec. $=$ minimum age specified.

\section{TABLE OF HEADINGS}

Antarctica

Commercial arbitration

Cultural matters

Cultural property

Development matters

Dispute settlement

Environment, fauna and flora

Family matters
Finance

Health

Human rights, including women and

children

Humanitarian law in armed conflict

Intellectual property

International crimes

International representation

\footnotetext{
* Compiled by Karin Arts, Associate Editor, Associate Professor in International Law and Development, Institute of Social Studies, The Hague.
}

Asian Yearbook of International Law, Volume 10 (B.S. Chimni et al., eds.)

(C) 2005 Koninklijke Brill NV. Printed in The Netherlands, pp. 265-290. 
International trade

Judicial and administrative

cooperation

Labour

Narcotic drugs

Nationality and statelessness

Nuclear material

Outer space

Privileges and immunities
Refugees

Road traffic and transport

Sea

Sea traffic and transport

Social matters

Telecommunications

Treaties

Weapons

\section{ANTARCTICA}

Antarctic Treaty, Washington, 1959: see Vol. 6 p. 234.

\section{COMMERCIAL ARBITRATION}

Convention on the Recognition and Enforcement of Foreign Arbitral Awards, 1958

(Continued from Vol. 8 p. 174)

$\begin{array}{lll}\text { State } & \text { Sig. } & \text { Cons. } \\ \text { Iran } & & 15 \text { Oct } 2001\end{array}$

\section{CULTURAL MATTERS}

Agreement for Facilitating the International Circulation of Visual and Auditory Materials of an Educational, Scientific and Cultural Character, Beirut, 1948: see Vol. 7 pp. 322-323. Agreement on the Importation of Educational, Scientific and Cultural Materials, Florence, 1950: see Vol. 8 p. 174.

Convention concerning the International Exchange of Publications, 1958: see Vol. 6 p. 235.

Convention concerning the International Exchange of Official Publications and Government Documents between States, 1958: see Vol. 6 p. 235.

International Agreement for the Establishment of the University for Peace, New York, 1980: see Vol. 6 p. 235.

\section{Regional Convention on the Recognition of Studies, Diploma's and Degrees in Higher} Education in Asia and the Pacific, Bangkok, 1983

(Continued from Vol. 6 p. 235 and corrected from Vol. 9 p. 282).

State Sig. Cons.

India 2 Aug 2000 


\section{CULTURAL PROPERTY}

Convention for the Protection of Cultural Property in the Event of Armed Conflict, 1954 (Continued from Vol. 7 p. 323 and corrected from Vol. 9 p. 282).

(Status as provided by UNESCO)

$\begin{array}{lll}\text { State } & \text { Sig. } & \text { Cons. } \\ \text { China } & \text { 14 May } 1954 & 5 \text { Jan } 2000\end{array}$

Protocol for the Protection of Cultural Property in the Event of Armed Conflict, 1954 (Continued from Vol. 6 p. 236 and corrected from Vol. 9 p. 282).

(Status as provided by UNESCO)

State Sig. Cons.

China $\quad 14$ May 19545 Jan 2000

Convention on the Means of Prohibiting and Preventing the Illicit Import, Export and Transfer of Ownership of Cultural Property, 1970

(Continued from Vol. 7 p. 323)

(Status as provided by UNESCO)

State Sig. Cons. State Sig. Cons.

$\begin{array}{llll}\text { Bhutan } & \text { 26 Sep } 2002 \quad \text { Japan }\end{array}$

Convention concerning the Protection of the World Cultural and Natural Heritage, 1972 (Continued from Vol. 7 p. 323)

(Status as provided by UNESCO)

State Sig. Cons.

Bhutan 17 Oct 2001

\section{DEVELOPMENT MATTERS}

Charter of the Asian and Pacific Development Centre, 1982, see Vol. 7 pp. 323-324. Agreement to Establish the South Centre, 1994, see Vol. 7 p. 324.

Amendments to the Charter of the Asian and Pacific Development Centre, 1982 Kuala Lumpur, 16 July 1998

$\begin{array}{llllll}\text { State } & \text { Sig. } & \text { Cons. } & \text { State } & \text { Sig. } & \text { Cons. } \\ \text { China } & & \text { 14 Sep 2001 } & \text { Vietnam } & & \text { 9 Jul 2001 } \\ \text { Malaysia } & \text { 14 May 2001 } & & \end{array}$




\section{DISPUTE SETTLEMENT}

Declarations recognizing as compulsory the jurisdiction of the International Court of Justice under Article 36, paragraph 2, of the Statute of the Court, see Vol. 6 p. 238.

\section{Convention on the Settlement of Investment Disputes between States and Nationals of Other States, 1965}

(Continued from Vol. 6 p. 238)

(Status as at 31 December 2002, provided by the World Bank)

\begin{tabular}{lll|lll} 
State & Sig. & Cons. & State & Sig. & Cons. \\
Brunei & 16 Sep 2002 & 16 Sep 2002 & Timor-Leste & 23 Jul 2002 & 23 Jul 2002 \\
Kazakhstan & 23 Jul 1992 & 21 Sep 2000 & & &
\end{tabular}

\section{ENVIRONMENT, FAUNA AND FLORA}

International Convention for the Prevention of Pollution of the Sea by Oil, as amended, 1954: see Vol. 6 p. 238.

International Convention Relating to Intervention on the High Seas in Cases of Oil Pollution Casualties, 1969: see

Vol. 9 p. 284.

Convention on the Prevention of Marine Pollution by Dumping of Wastes and Other Matter, 1972, as amended: see Vol. 7 p. 325.

Protocol Relating to Intervention on the High Seas in Cases of Pollution by Substances Other Than Oil, 1973: see Vol. 6 p. 239.

Protocol to amend the 1971 Convention on Wetlands of International Importance especially as Waterfowl Habitat, 1982: see Vol. 6 p. 240.

International Convention on Oil Pollution Preparedness, Response, and Cooperation, 1990: see Vol. 9 p. 285.

\section{International Convention on Civil Liability for Oil Pollution Damage, 1969 \\ (Continued from Vol. 9 p. 284) \\ (Status as included in IMO doc. 8687, as at 31 December 2003)}

$\begin{array}{llllll}\text { State } & \text { Denunciation } & \text { E.i.f. } & \text { State } & \text { Denunciation } & \text { E.i.f. } \\ \text { Brunei } & \text { 31 Jan } 2002 & & \begin{array}{l}\text { Papua New } \\ \text { Guinea }\end{array} & \text { 23 Jan 2001 } & \text { 22 Jan } 2002\end{array}$


Convention on Wetlands of International Importance especially as Waterfowl Habitat, 1971

(continued from Vol. 7 p. 325)

(Status as provided by UNESCO)

\begin{tabular}{ll|ll} 
State & Cons. (deposit) & State & Cons. (deposit) \\
Kyrgyzstan & 12 Nov 2002 & Uzbekistan & 8 Oct 2001 \\
Tajikistan & 18 Jul 2001 & &
\end{tabular}

\section{International Convention on the Establishment of an International Fund for Compensation for Oil Pollution Damage, 1971 \\ (Continued and corrected from Vol. 9 p. 284) \\ (Status as included in IMO doc. 8687, as at 31 December 2003)}

\begin{tabular}{lll|lll} 
State & Denunciation & E.i.f. & State & Denunciation & E.i.f. \\
China & 5 Jan 1999 & 5 Jan 2000 & Papua New & & \\
India & 21 Jun 2000 & 21 Jun 2001 & Guinea & 23 Jan 2001 & 23 Jan 2002
\end{tabular}

\section{Protocol to the International Convention on Civil Liability for Oil Pollution} Damage, 1976

(Continued from Vol. 6 p. 239)

(Status as included in IMO doc. 8687, as at 31 December 2003)

$\begin{array}{lll}\text { State } & \text { Cons. } & \text { E.i.f. } \\ \text { Cambodia } & 8 \text { Jun 2001 } & \text { 6 Sept 2001 }\end{array}$

Protocol Relating to the 1973 International Convention for the Prevention of Pollution from Ships, as amended, 1978

(Continued from Vol. 8 p. 176).

(Status as included in IMO doc. 8687, as at 31 December 2003)

\begin{tabular}{lll|lll} 
State & $\begin{array}{l}\text { Cons. } \\
\text { (deposit) }\end{array}$ & $\begin{array}{l}\text { Excepted } \\
\text { Annexes }\end{array}$ & State & $\begin{array}{l}\text { Cons. } \\
\text { (deposit) }\end{array}$ & $\begin{array}{l}\text { Excepted } \\
\text { Annexes }\end{array}$ \\
Bangladesh & 18 Dec 2002 & & Philippines & 15 Jun 2001 & \\
Iran & 25 Oct 2002 & III and IV & &
\end{tabular}

Convention for the Protection of the Ozone Layer, 1985

(Continued from Vol. 9 p. 284)

State Cons.

Cambodia 27 Jun 2001 
Protocol on Substances that Deplete the Ozone Layer, 1987

(Continued from Vol. 9 p. 284)

State Cons.

Cambodia 27 Jun 2001

Amendments to Articles 6 and 7 of the 1971 Convention on Wetlands of International Importance especially as Waterfowl Habitat, 1987

(Continued from Vol. 6 p. 240)

State Cons. (deposit)

Uzbekistan 8 Oct 2001

Convention on the Control of Transboundary Movements of Hazardous Wastes and Their Disposal, 1989

(Continued from Vol. 7 p. 325)

$\begin{array}{llllll}\text { State } & \text { Sig. } & \text { Cons. } & \text { State } & \text { Sig. } & \text { Cons. } \\ \begin{array}{l}\text { Cambodia } \\ \text { Bhutan }\end{array} & \text { 2 Mar 2001 } & \text { Brunei } & & 16 \text { Dec } 2002\end{array}$

Amendment to the Montreal Protocol, 1990

(Continued from Vol. 8 p. 177)

State Cons.

Kazakhstan 26 Jul 2001

Framework Convention on Climate Change, 1992

(Continued from Vol. 9 p. 285)

State Sig Cons

Afghanistan 21 Jun 1992 19 Sep 2002

Convention on Biological Diversity, 1992

(Continued from Vol. 7 p. 326)

State Sig. Cons.

Afghanistan 12 Jun $92 \quad 19$ Sep 2002 
Amendment to the Montreal Protocol, 1992

(Continued from Vol. 9 p. 284)

$\begin{array}{llll}\text { State } & \text { Cons. } & \text { State } & \text { Cons. } \\ \text { Maldives } & \text { 27 Sep 2001 } & \text { Philippines } & \text { 15 Jun } 2001\end{array}$

Protocol to amend the 1969 International Convention on Civil Liability for Oil Pollution Damage, 1992

(Continued from Vol. 8 p. 176)

(Status as included in IMO doc. 8687, as at 31 December 2003)

\begin{tabular}{|c|c|c|c|c|c|}
\hline State & Cons. & E.i.f. & State & Cons. & E.i.f. \\
\hline Brunei & 3 Jan 2002 & & Papua New & & \\
\hline Cambodia & 8 Jun 2001 & 8 Jun 2002 & Guinea & 23 Jan 2001 & 23 Jan 2002 \\
\hline
\end{tabular}

\section{UN Convention to Combat Desertification in those Countries Experiencing Serious Drought and/or Desertification, Particularly in Africa}

Paris, 14 October 1994

Entry into Force: 26 December 1996

\begin{tabular}{|c|c|c|c|c|c|}
\hline State & Sig. & Cons. & State & Sig. & Cons. \\
\hline Afghanistan & & 1 Nov 1995 & Mongolia & 15 Oct 1994 & 3 Sep 1996 \\
\hline Bangladesh & 14 Oct 1994 & 26 Jan 1996 & Myanmar & & 2 Jan 1997 \\
\hline Brunei & & $4 \operatorname{Dec} 2002$ & Nepal & 12 Oct 1995 & 15 Oct 1996 \\
\hline Cambodia & 15 Oct 1994 & 18 Aug 1997 & Pakistan & 15 Oct 1994 & 24 Feb 1997 \\
\hline China & 14 Oct 1994 & 18 Feb 1997 & Papua New & & \\
\hline India & 14 Oct 1994 & 17 Dec 1996 & Guinea & & 6 Dec 2000 \\
\hline Indonesia & 15 Oct 1994 & 31 Aug 1998 & Philippines & 8 Dec 1994 & 10 Feb 2000 \\
\hline Iran & 14 Oct 1994 & 29 Apr 1997 & Singapore & & 26 Apr 1999 \\
\hline Japan & 14 Oct 1994 & 11 Sep 1998 & Sri Lanka & & 9 Dec 1998 \\
\hline Kazakhstan & 14 Oct 1994 & 9 Jul 1997 & Tajikistan & & 16 Jul 1997 \\
\hline Korea (Rep.) & 14 Oct 1994 & 17 Aug 1999 & Thailand & & 7 Mar 2001 \\
\hline Laos & 30 Aug 1995 & 20 Sep 1996 & Turkmenistan & 27 Mar 1995 & 18 Sep 1996 \\
\hline Malaysia & 6 Oct 1995 & 25 Jun 1997 & Uzbekistan & 7 Dec 1994 & 31 Oct 1995 \\
\hline Maldives & & 3 Sep 2002 & Vietnam & & 25 Aug 1998 \\
\hline
\end{tabular}

\section{Amendment to the Convention on the Control of Transboundary Movements of} Hazardous Wastes and Their Disposal, 1995

(Continued from Vol. 8 p. 178)

$\begin{array}{llllll}\text { State } & \text { Sig. } & \text { Cons. } & \text { State } & \text { Sig. } & \text { Cons. } \\ \text { Brunei } & & \text { 6 Dec 2002 } & \text { Malaysia } & & 26 \text { Oct 2001 } \\ \text { China } & 1 \text { May 2001 } & & \end{array}$


Amendment to the Montreal Protocol, 1997

(Continued from Vol. 9 p. 285)

\begin{tabular}{ll|ll} 
State & Cons. & State & Cons. \\
Bangladesh & 27 Jul 2001 & Malaysia & 26 Oct 2001 \\
Iran & 17 Oct 2001 & Maldives & 27 Sep 2001 \\
Japan & 30 Aug 2002 & Mongolia & 28 Mar 2002 \\
Korea (DPR) & 13 Dec 2001 & &
\end{tabular}

Protocol to the Framework Convention on Climate Change, 1997 (Continued from Vol. 8 p. 177)

\begin{tabular}{|c|c|c|c|c|c|}
\hline State & Sig. & Cons. & State & Sig. & Cons. \\
\hline Bangladesh & & 22 Oct 2001 & Malaysia & 12 Mar 1999 & 4 Sep 2002 \\
\hline Bhutan & & 26 Aug 2002 & Papua New & & \\
\hline Cambodia & & 22 Aug 2002 & Guinea & 2 Mar 1999 & 28 Mar 2002 \\
\hline China & 29 May 1998 & 30 Aug 2002 & Sri Lanka & & 3 Sep 2002 \\
\hline India & & 26 Aug 2002 & Thailand & 2 Feb 1999 & 28 Aug 2002 \\
\hline Japan & 28 Apr 1998 & 4 Jun 2002 & Vietnam & 3 Dec 1998 & 25 Sep 2002 \\
\hline Korea (Rep.) & 25 Sep 1998 & 8 Nov 2002 & & & \\
\hline
\end{tabular}

Amendment to the Montreal Protocol, 1999

Beijing, 3 December 1999

Entry into force: 25 February 2002

\begin{tabular}{ll|ll} 
State & Cons. & State & Cons. \\
Japan & 30 Aug 2002 & Malaysia & 26 Oct 2001 \\
Korea (DPR) & 13 Dec 2001 & Sri Lanka & 27 Nov 2002
\end{tabular}

\section{Cartagena Protocol on Biosafety to the Convention on Biological Diversity Montreal, 29 January 2000 \\ Entry into force: not yet}

\begin{tabular}{ll|ll} 
State & Sig. & State & Sig. \\
Bangladesh & 24 May 2000 & Malaysia & 24 May 2000 \\
Bhutan & 26 Aug 2002 & Maldives & 3 Sep 2002 \\
China & 8 Aug 2000 & Myanmar & 11 May 2001 \\
India & 23 Jan 2001 & Nepal & 2 Mar 2001 \\
Indonesia & 24 May 2000 & Pakistan & 4 Jun 2001 \\
Iran & 23 Apr 2001 & Philippines & 24 May 2000 \\
Korea (DPR) & 20 Apr 2001 & Sri Lanka & 24 May 2000 \\
Korea (Rep.) & 6 Sep 2000 & &
\end{tabular}




\section{FAMILY MATTERS}

Convention on the Recovery Abroad of Maintenance, 1956: see Vol. 6 p. 243.

Convention on the Law Applicable to Maintenance Obligations Towards Children, 1956: see Vol. 6 p. 244.

Convention on the Conflicts of Law Relating to the Form of Testamentary Dispositions, 1961: see Vol. 7 p. 327.

Convention on Consent to Marriage, Minimum Age for Marriage and Registration of Marriages, 1962: see Vol. 8 p. 178.

Convention on the Law Applicable to Maintenance Obligations, 1973: see Vol. 6 p. 244. Convention on Protection of Children and Co-operation in respect of Intercountry Adoption, 1993: see Vol. 9 p. 285.

\section{FINANCE}

Agreement Establishing the Asian Development Bank, 1965: see Vol. 7 p. 327.

\section{Convention Establishing the Multilateral Investment Guarantee Agency, 1988}

(Continued from Vol. 9 p. 286)

(Status as at 31 December 2002, provided by the World Bank)

State Sig. Cons. State Sig. Cons.

\begin{tabular}{ll|ll} 
Tajikistan & 9 Dec $2002 \quad$ Timor-Leste & 23 Jul 2002
\end{tabular}

\section{HEALTH}

Protocol Concerning the Office International d'Hygiène Publique, 1946: see Vol. 6 p. 245.

\section{HUMAN RIGHTS, INCLUDING WOMEN AND CHILDREN}

Convention against Discrimination in Education, 1960: see Vol. 7 p. 328.

International Covenant on Civil and Political Rights, 1966: see Vol. 9 p. 287.

Optional Protocol to the International Covenant on Civil and Political Rights, 1966: see Vol. 8 p. 179 .

International Convention on the Elimination of All Forms of Racial Discrimination, 1966: see Vol. 8 p. 179.

International Convention against Apartheid in Sports, 1985: see Vol. 6 p. 248.

Convention on the Rights of the Child, 1989: see Vol. 7 p. 329.

\section{Convention on the Political Rights of Women, 1953}

(Continued from Vol. 9 p. 286)

State Sig. Cons.

Cambodia $\quad 11$ Nov 2001 
Convention on the Nationality of Married Women, 1957

(Continued from Vol. 9 p. 286)

State Sig. Cons.

Cambodia $\quad 11$ Nov 2001

International Covenant on Economic, Social and Cultural Rights, 1966

(Continued from Vol. 9 p. 287)

$\begin{array}{lll}\text { State } & \text { Sig. } & \text { Cons. } \\ \text { China } & \text { 27 Oct 1997 } & \text { 27 Mar 2001 }\end{array}$

Convention on the Elimination of All Forms of Discrimination against Women, 1979

(Continued from Vol. 8 p. 180)

State Sig. Cons.

Korea (DPR) 27 Feb 2001

Convention against Torture and Other Cruel, Inhuman or Degrading Treatment or Punishment, 1984

(Continued from Vol. 8 p. 180)

State Sig. Cons.

Mongolia 24 Jan 2002

International Convention on the Protection of the Rights of All Migrant Workers and Members of Their Families, 1990

(Continued from Vol. 8 p. 180)

State Sig. Cons.

Tajikistan $\quad 7$ Sep $2000 \quad 8$ Jan 2002

Amendment to article 8 of the International Convention on the Elimination of All Forms of Racial Discrimination, 1992

(Continued from Vol. 6 p. 247)

State Sig. Cons.

China $\quad 10$ Jul 2002 
Optional Protocol to the Convention on the Elimination of All Forms of Discrimination against Women, 1999

(Continued from Vol. 9 p. 287)

\begin{tabular}{|c|c|c|c|c|c|}
\hline State & Sig. & Cons. & State & Sig. & Cons. \\
\hline Cambodia & 11 Nov 2001 & & Mongolia & 7 Sep 2000 & 28 Mar 20 \\
\hline Kazakhstan & 6 Sep 2000 & 24 Aug 2001 & $\begin{array}{l}\text { Nepal } \\
\text { Sri Lanka }\end{array}$ & 18 Dec 2001 & 5 Oct 20 \\
\hline
\end{tabular}

\section{Optional Protocol to the Convention on the Rights of the Child on the Involvement of Children in Armed Conflict, 2000 \\ (Continued from Vol. 9 p. 287)}

\begin{tabular}{ll|lll} 
State & Sig. & State & Sig. & Cons. \\
& & Cons. & Mongolia & 12 Nov 2001 \\
China & 15 Mar 2001 & Pakistan & 26 Sep 2001 & \\
Indonesia & 24 Sep 2001 & Vietnam & 8 Sep 2000 & 20 Dec 2001 \\
Japan & 10 May 2002 & Tajikistan & & 5 Aug 2002 \\
Maldives & 10 May 2002 & &
\end{tabular}

Optional Protocol to the Convention on the Rights of the Child on the Sale of Children, Child Prostitution and Child Pornography, 2000

(Continued from Vol. 9 p. 287)

\begin{tabular}{lll|lll} 
State & Sig. & Cons. & State & Sig. & Cons. \\
& & & & & \\
Afghanistan & & 19 Sep 2002 & Mongolia & 12 Nov 2001 & \\
Cambodia & 27 Jun 2000 & 30 May 2002 & Pakistan & 26 Sep 2001 & \\
China & 6 Sep 2000 & 3 Dec 2002 & Sri Lanka & 8 May 2002 & \\
Japan & 10 May 2002 & & Tajikistan & & 5 Aug 2002 \\
Kazakhstan & 6 Sep 2000 & 24 Aug 2001 & Vietnam & 8 Sep 2000 & 20 Dec 2001 \\
Maldives & 10 May 2002 & 10 May 2002 & & &
\end{tabular}

\section{HUMANITARIAN LAW IN ARMED CONFLICT}

International Conventions for the Protection of Victims of War, I-IV, 1949: see Vol. 6 p. 249.

Protocol I Additional to the Geneva Conventions of 12 August 1949, and Relating to the Protection of Victims of International Armed Conflicts, 1977: see Vol. 7 p. 330. Protocol II Additional to the Geneva Conventions of 12 August 1949, and Relating to the Protection of Victims of Non-International Armed Conflicts, 1977: see Vol. 7 p. 329.

\section{INTELLECTUAL PROPERTY}

Convention for the Protection of Literary and Artistic Works, 1886 as amended 1979, see Vol. 9 p. 289.

Universal Copyright Convention, 1952: see Vol. 6 p. 251. 
Protocols 1, 2 and 3 annexed to the Universal Copyright Convention, 1952: see Vol. 6 p. 251.

International Convention for the Protection of Performers, Producers of Phonograms and Broadcasting Organizations, 1961: see Vol. 6 p. 252.

Multilateral Convention for the Avoidance of Double Taxation of Copyright Royalties, 1979: see Vol. 6 p. 252.

\section{Convention for the Protection of Industrial Property, 1883 as amended 1979 \\ (Continued from Vol. 9 p. 288)}

(Status as included in WIPO doc. 423(E) of 15 Jan 2003)

$\begin{array}{lll}\text { State } & \text { Party } & \begin{array}{l}\text { Latest Act } \\ \text { to which } \\ \text { State is party }\end{array} \\ \text { Nepal } & \text { 22 Jun 2001 } & \text { Stockholm }\end{array}$

\section{Convention Establishing the World Intellectual Property Organization, 1967}

(Continued from Vol. 6 p. 252)

(Status as included in WIPO doc. 423(E) of 15 Jan 2003)

$\begin{array}{llll}\text { State } & \text { Membership } & \text { State } & \text { Membership } \\ \text { Iran } & 14 \text { Mar 2002 } & \text { Myanmar } & \text { 15 May 2001 }\end{array}$

\section{Convention for the Protection of Producers of Phonograms against Unauthorized Duplication of their Phonograms, 1971 \\ (Continued from Vol. 8 p. 181)}

$\begin{array}{llllll}\text { State } & \text { Sig. } & \text { Cons. } & \text { State } & \text { Sig. } & \text { Cons. } \\ \text { Kazakhstan } & \text { 3 May 2001 } & \text { Kyrgyzstan } & \text { 12 Jul } 2002\end{array}$

\section{INTERNATIONAL CRIMES}

Convention on the Prevention and Punishment of the Crime of Genocide, 1948: see Vol. 8 p. 182.

Slavery Convention, 1926 as amended in 1953, see Vol. 7 p. 331.

Supplementary Convention on the Abolition of Slavery, the Slave Trade, and Institutions and Practices Similar to Slavery, 1956, see Vol. 7 p. 331.

Convention on Offences and Certain Other Acts Committed on Board Aircraft, 1963: see Vol. 9 p. 289.

Convention on the Non-Applicability of Statutory Limitations to War Crimes and Crimes Against Humanity, 1968: see Vol. 6 p. 254.

Convention for the Suppression of Unlawful Seizure of Aircraft, 1970: see Vol. 8 p. 289. Convention for the Suppression of Unlawful Acts Against the Safety of Civil Aviation, 1971: see Vol. 8 p. 290. 
International Convention on the Suppression and Punishment of the Crime of Apartheid, 1973: see Vol. 7 p. 331.

International Convention against the Recruitment, Use, Financing and Training of Mercenaries, 1989: see Vol. 8 p. 184.

\section{Convention on the Prevention and Punishment of Crimes Against Internationally Protected Persons Including Diplomatic Agents, 1973 \\ (Continued from Vol. 8 p. 183)}

\begin{tabular}{|c|c|c|c|c|c|}
\hline State & Sig. & Cons. & State & Sig. & Cons. \\
\hline Laos & & 22 Aug 2002 & Vietnam & & 2 May 2002 \\
\hline Tajikistan & & 19 Oct 2001 & & & \\
\hline
\end{tabular}

International Convention Against the Taking of Hostages, 1979

(Continued from Vol. 9 p. 290)

\begin{tabular}{|c|c|c|c|c|c|}
\hline State & Sig. & Cons. & State & Sig. & Cons. \\
\hline Korea (DPR) & & 12 Nov 2001 & Tajikistan & & 6 May 2002 \\
\hline Laos & & 22 Aug 2002 & & & \\
\hline
\end{tabular}

\section{Convention for the Suppression of Unlawful Acts Against the Safety of Maritime Navigation, 1988}

(Corrected and continued from Vol. 9 p. 290)

(Status as included in IMO doc. 8687, as at 31 December 2003)

$\begin{array}{lll}\text { State } & \text { Cons } & \text { E.i.f. } \\ \text { Vietnam } & \text { 12 Jul } 2000 & 10 \text { Oct } 2002\end{array}$

Protocol for the Suppression of Unlawful Acts Against the Safety of Fixed Platforms Located on the Continental Shelf, 1988

(Corrected and continued from Vol. 8 p. 183)

(Status as included in IMO doc. 8687, as at 31 December 2003)

$\begin{array}{lll}\text { State } & \text { Cons } & \text { E.i.f. } \\ \text { Vietnam } & \text { 12 Jul } 2002 & 10 \text { Oct } 2002\end{array}$ 
Protocol for the Suppression of Unlawful Acts of Violence at Airports Serving International Civil Aviation, Supplementary to the Convention for the Suppression of Unlawful Acts Against the Safety of Civil Aviation, 1988

(Continued from Vol. 9 p. 290)

(Status as at 31 December 2002 provided by the ICAO Secretariat)

\begin{tabular}{lll|lll} 
State & Cons. & Eff. date. & State & Cons. & Eff. date. \\
Brunei & 20 Dec 2000 & 19 Jan 2001 & Papua New & & \\
Iran & 14 Feb 2002 & 16 Mar 2002 & Guinea & 11 Jul 2002 & 10 Aug 2002 \\
Laos & 7 Oct 2002 & 6 Nov 2002 & & &
\end{tabular}

Convention on the Marking of Plastic Explosives for the Purpose of Detection, 1991 (Continued from Vol. 8 p. 291)

(Status as at 31 December 2002 provided by the ICAO Secretariat)

$\begin{array}{llllll}\text { State } & \text { Sig. } & \text { Cons. } & \text { State } & \text { Sig. } & \text { Cons. } \\ \text { Korea (Rep.) } & \text { 2 Jan 2002 } & \text { 3 Mar 2002 } & \text { Sri Lanka } & \text { 11 Oct 2001 } & 10 \text { Dec } 2001\end{array}$

Convention on the Safety of United Nations and Associated Personnel, 1994

New York, 9 December 1994

Entry into force: 15 January 1999

\begin{tabular}{lll|lll} 
State & Sig. & Cons. & State & Sig. & Cons. \\
Bangladesh & 21 Dec 1994 & 22 Sep 1999 & Pakistan & 8 Mar 1995 & \\
Brunei & & 20 Mar 2002 & Philippines & 27 Feb 1995 & 17 Jun 1997 \\
Japan & 6 Jun 1995 & 6 Jun 1995 & Singapore & 26 Mar 1996 \\
Korea (Rep.) & & 8 Dec 1997 & Turkmenistan & 29 Aug 1998 \\
Laos & 22 Aug 2002 & Uzbekistan & 3 Jul 1996 \\
Nepal & 8 Sep 2000 & & &
\end{tabular}

International Convention for the Suppression of Terrorist Bombings, 1997

New York, 15 December 1997

Entry into force: 23 May 2001

\begin{tabular}{|c|c|c|c|c|c|}
\hline State & Sig. & Rat. & State & Sig. & Rat. \\
\hline Brunei & & 14 Mar 2002 & Mongolia & & 7 Sep 2000 \\
\hline China & & 13 Nov 2001 & Myanmar & & 12 Nov 2001 \\
\hline India & 17 Sep 1999 & 22 Sep 1999 & Nepal & 24 Sep 1999 & \\
\hline Japan & 17 Apr 1998 & 16 Nov 2001 & Pakistan & & 13 Aug 2002 \\
\hline Kazakhstan & & 6 Nov 2002 & Philippines & 23 Sep 1998 & \\
\hline Korea (Rep.) & 3 Dec 1999 & & Sri Lanka & 12 Jan 1998 & 23 Mar 1999 \\
\hline Kyrgyzstan & & 1 May 2001 & Tajikistan & & $29 \mathrm{Jul} 2002$ \\
\hline Laos & & 22 Aug 2002 & Turkmenistan & 18 Feb 1999 & 25 Jun 1999 \\
\hline Maldives & & 7 Sep 2000 & Uzbekistam & 23 Feb 1998 & 30 Nov 1998 \\
\hline
\end{tabular}




\section{Statute of the International Criminal Court, 1998}

Rome, 17 July 1998

Entry into force: 1 July 2002

\begin{tabular}{lll|lll} 
State & Sig. & Rat. & State & Sig. & Rat. \\
& & & Philippines & 28 Dec 2000 & \\
Bangladesh & 16 Sep 1999 & & $\begin{array}{l}\text { Tajikistan } \\
\text { 30 Nov 1998 }\end{array}$ & 5 May 2000 \\
Cambodia & 23 Oct 2000 & 11 Apr 2002 & $\begin{array}{l}\text { Thailand } \\
\text { 2 Oct 2000 }\end{array}$ & \\
Iran & 31 Dec 2000 & & Timor-Leste & & 6 Sep 2002 \\
Korea (Rep.) & 8 Mar 2000 & 13 Nov 2002 & Timekistan & 29 Dec 2000 & \\
Kyrgyzstan & 8 Dec 1998 & & & &
\end{tabular}

\section{International Convention for the Suppression of the Financing of Terrorism} New York, 9 December 1999

Entry into force:

10 April 2002

\begin{tabular}{lll|llll} 
State & Sig. & \multicolumn{2}{c}{ Rat. } & State & Sig. & Rat. \\
& & & & \\
Bhutan & 14 Nov 2001 & & Mongolia & 12 Nov 2001 & \\
Brunei & & 4 Dec 2002 & Myanmar & 12 Nov 2001 & \\
Cambodia & 11 Nov 2001 & & Philippines & 16 Nov 2001 & \\
China & 13 Nov 2001 & & Singapore & 18 Dec 2001 & 30 Dec 2002 \\
India & 8 Sep 2000 & & Sri Lanka & 10 Jan 2000 & 8 Sep 2000 \\
Indonesia & 24 Sep 2001 & & Tajikistan & 6 Nov 2001 & \\
Japan & 20 Oct 2001 & 11 Jun 2002 & Thailand & 18 Dec 2001 & \\
Korea (DPR) & 12 Nov 2001 & & Uzbekistan & 13 Dec 2000 & 9 Jul 2001 \\
Korea (Rep.) & 9 Oct 2001 & & Vietnam & & 25 Sep 2002
\end{tabular}

INTERNATIONAL REPRESENTATION

(see also: Privileges and Immunities)

Vienna Convention on the Representation of States in their relations with International Organizations of a Universal Character, 1975: see Vol. 6 p. 257.

\section{INTERNATIONAL TRADE}

Convention on Transit Trade of Land-locked States, 1965: see Vol. 6 p. 257.

Convention on the Limitation Period in the International Sale of Goods, 1974: see Vol. 6 p. 257.

UN Convention on Contracts for the International Sale of Goods, 1980: see Vol. 8 p. 184.

UN Convention on the Liability of Operators of Transport Terminals in International Trade, 1991: see Vol. 6 p. 257. 


\section{JUDICIAL AND ADMINISTRATIVE COOPERATION}

Convention Relating to Civil Procedure, 1954: see Vol. 6 p. 258.

Convention on the Service Abroad of Judicial and Extrajudicial Documents in Civil or Commercial Matters, 1965: see Vol. 9 p. 291.

Convention on the Taking of Evidence Abroad in Civil or Commercial Matters, 1970: see Vol. 9 p. 292.

\section{Convention Abolishing the Requirement of Legalisation for Foreign Public Documents, 1961}

(Corrected from Vol. 9 p. 332)

(Status as provided by The Hague Conference on Private International Law)

State Sig. Cons.

Kazakhstan 5 Apr $2000 \quad 30$ Jan 2001

\section{LABOUR}

Freedom of Association and Protection of the Right to Organise Convention, 1948 (ILO Conv. 87): see Vol. 9 p. 292.

Discrimination (Employment and Occupation) Convention, 1958 (ILO Conv. 111): see Vol. 8 p. 185.

Employment Policy Convention, 1964 (ILO Conv. 122): see Vol. 8 p. 186.

Forced Labour Convention, 1930 (ILO Conv. 29)

(Continued from Vol. 7 p. 333)

(Status as at 31 December 2002 as provided by the ILO)

$\begin{array}{llll}\text { State } & \text { Ratif. } \text { Registered } & \text { State } & \text { Ratif. Registered } \\ \text { Kazakhstan } & \text { 18 May 2001 } & \text { Nepal } & \text { 3 Jan } 2002\end{array}$

Right to Organise and Collective Bargaining Convention, 1949 (ILO Conv. 98)

(Continued from Vol. 8 p. 185)

(Status as at 31 December 2002 as provided by the ILO)

State Ratif. Registered

Kazakhstan 18 May 2001 
Equal Remuneration Convention, 1951 (ILO Conv. 100)

(Continued from Vol. 8 p. 185)

(Status as at 31 December 2002 as provided by the ILO)

\begin{tabular}{ll|ll} 
State & Ratif. Registered & State & Ratif. Registered \\
Kazakhstan & 18 May 2001 & Singapore & 30 May 2002 \\
Pakistan & 11 Oct 2001 & &
\end{tabular}

Abolition of Forced Labour Convention, 1957 (ILO Conv. 105)

(Continued from Vol. 9 p. 292)

(Status as at 31 December 2002 as provided by the ILO)

State Ratif. registered

Kazakhstan 18 May 2001

Minimum Age Convention, 1973 (ILO Conv. 138)

Entry into force: 19 June 1976

(Corrected from Vol. 9 p. 293)

(Status as at 31 December 2002 as provided by the ILO)

\begin{tabular}{lll|lll} 
State & Ratif. Reg. & $\begin{array}{l}\text { Min. age } \\
\text { spec. }\end{array}$ & State & Ratif. Reg. & $\begin{array}{l}\text { Min. age } \\
\text { spec. }\end{array}$ \\
Cambodia & 23 Aug 1999 & 14 & Mongolia & 16 Dec 2002 & 15 \\
China & 28 Apr 1999 & 16 & Nepal & 30 May 1997 & 14 \\
Indonesia & 7 Jun 1999 & 15 & Papua New & & \\
Japan & 5 Jun 2000 & 15 & Guinea & 2 Jun 2000 & 16 \\
Kazakhstan & 18 May 2001 & 16 & Philippines & 4 Jun 1998 & 15 \\
Korea (Rep.) & 28 Jan1999 & 15 & Sri Lanka & 11 Feb 2000 & 14 \\
Kyrgyzstan & 31 Mar 1992 & 16 & Tajikistan & 26 Nov 1993 & 16 \\
Malaysia & 9 Sep 1997 & 15 & & &
\end{tabular}

Worst Forms of Child Labour Convention, 1999 (ILO Conv. 182)

(Continued from Vol. 9 p. 293)

(Status as at 31 December 2002 as provided by the ILO)

\begin{tabular}{ll|ll} 
State & Ratif. registered & State & Ratif. registered \\
& & Nepal & 3 Jan 2002 \\
Bangladesh & 12 Mar 2001 & Pakistan & 11 Oct 2001 \\
China & 8 Aug 2002 & Singapore & 14 Jun 2001 \\
Iran & 8 May 2002 & Sri Lanka & 1 Mar 2001 \\
Japan & 18 Jun 2001 & Thailand & 16 Feb 2001 \\
Korea (Rep.) & 29 Mar 2001 & &
\end{tabular}




\section{NARCOTIC DRUGS}

Agreement Concerning the Suppression of the Manufacture of, Internal Trade in, and Use of, Prepared Opium and amended by Protocol, 1925, amended 1946: see Vol. 6 p. 261.

Agreement Concerning the Suppression of Opium Smoking, 1931, amended by Protocol, 1946: see Vol. 6 p. 261.

Protocol Amending the Agreements, Conventions and Protocols on Narcotic Drugs, concluded at The Hague on 23 January 1912, at Geneva on 11 February 1925 and 19 February 1925 and 13 July 1931, at Bangkok on 27 November 1931 and at Geneva on 26 June 1936, 1946: see Vol. 6 p. 261.

Protocol bringing under International Control Drugs outside the Scope of the Convention of 1931, as amended by the protocol of 1946: see Vol. 6 p. 262.

Convention for the Suppression of the Illicit Traffic in Dangerous Drugs, 1936, amended 1946: see Vol. 6 p. 262.

Protocol for Limiting and Regulating the Cultivation of the Poppy Plant, the Production of, International and Wholesale Trade in, and Use of Opium, 1953: see Vol. 6 p. 262. International Opium Convention, 1925, amended by Protocol 1946: see Vol. 7 p. 334. Convention for Limiting the Manufacture and Regulating the Distribution of Narcotic Drugs, 1931, and amended by Protocol, 1946: see Vol. 7 p. 334.

Single Convention on Narcotic Drugs, 1961: see Vol. 7 p. 334.

Convention on Psychotropic Substances, 1971: see Vol. 9 p. 294.

United Nations Convention Against Illicit Traffic in Narcotic Drugs and Psychotropic Substances, 1988: see Vol. 9 p. 294.

\section{Single Convention on Narcotic Drugs, 1961, as Amended by Protocol 1972}

(Continued from Vol. 9 p. 294)

State Sig. Cons.

Iran 18 Dec 2001

Protocol amending the Single Convention on Narcotic Drugs, 1972

(Continued from Vol. 8 p. 186)

State Sig. Cons.

Iran $\quad 25$ Mar 197218 Dec 2001

\section{NATIONALITY AND STATELESSNESS}

Convention relating to the Status of Stateless Persons, 1954: see Vol. 6 p. 264.

Optional Protocol to the Vienna Convention on Diplomatic Relations concerning Acquisition of Nationality, 1961: see Vol. 6 p. 265.

Optional Protocol to the Vienna Convention on Consular Relations concerning Acquisition of Nationality, 1963: see Vol. 8 p. 187. 


\section{NUCLEAR MATERIAL}

Convention on Civil Liability for Nuclear Damage, 1963: see Vol. 6 p. 265.

Joint Protocol Relating to the Application of the Vienna Convention (and the Paris Convention on Third Party Liability in the Field of Nuclear Energy), 1980: see Vol. 6 p. 265.

Convention on Early Notification of a Nuclear Accident, 1986: see Vol. 9 p. 295.

Convention on Assistance in the Case of a Nuclear Accident or Radiological Emergency, 1986: see Vol. 9 p. 295.

Protocol to amend the Convention on Civil Liability for Nuclear Damage, 1997: see Vol. 8 p. 188.

Convention on Supplementary Compensation for Nuclear Damage, 1997: see Vol. 8 p. 189.

\section{Convention on the Physical Protection of Nuclear Material, 1980}

(Continued from Vol. 9 p. 295)

(Status as at 31 December 2002, provided by IAEA)

State Sig. Cons. (deposit)

India 12 Mar 2002

Convention on Nuclear Safety, 1994

(Continued from Vol. 8 p. 188)

(Status as at 31 December 2002, provided by IAEA)

State Sig. Cons. (deposit)

Indonesia $\quad 12$ Apr 2002

Joint Convention on the Safety of Spent Fuel Management and on the Safety of Radioactive Waste Management, 1997

Entry into force: 18 Jun 2001

(Continued from Vol. 8 p. 188)

(Status as at 31 December 2002, provided by IAEA)

State Sig. Cons. (deposit)

Korea (Rep.) 16 Sep 2002

\section{OUTER SPACE}

Treaty on Principles Governing the Activities of the States in the Exploration and Use of Outer Space, Including the Moon and Other Celestial Bodies, 1967: see Vol. 6 p. 266. 
Agreement governing the Activities of States on the Moon and other Celestial Bodies, 1979

(Continued from Vol. 6 p. 267)

State Sig. Cons.

Kazakhstan $\quad$ 11 Jan 2001

Convention on Registration of Objects Launched into Outer Space, 1974

(Continued from Vol. 7 p. 337).

State Sig. Cons.

Kazakhstan $\quad 11$ Jan 2001

\section{PRIVILEGES AND IMMUNITIES}

Convention on the Privileges and Immunities of the Specialized Agencies, 1947: see Vol. 7 p. 338.

Vienna Convention on Diplomatic Relations, 1961: see Vol. 6 p. 268.

Optional Protocol to the Vienna Convention on Diplomatic Relations concerning the Compulsory Settlement of Disputes, 1961: see Vol. 6 p. 269.

Vienna Convention on Consular Relations, 1963: see Vol. 8 p. 189.

Optional Protocol to the Vienna Convention on Consular Relations concerning the Compulsory Settlement of Disputes, 1963: see Vol. 6 p. 269.

Convention on Special Missions, 1969: see Vol. 6 p. 269.

Optional Protocol to the Convention on Special Missions concerning the Compulsory Settlement of Disputes, 1969: see Vol. 6 p. 269.

\section{Convention on the Privileges and Immunities of the United Nations, 1946 \\ (Continued from Vol. 9 p. 296)}

State Sig. Cons.

Tajikistan 19 Oct 2001

\section{REFUGEES}

Convention relating to the Status of Refugees, 1951: see Vol. 8 p. 190.

Protocol relating to the Status of Refugees, 1967: see Vol. 8 p. 190.

\section{ROAD TRAFFIC AND TRANSPORT}

Convention on Road Traffic, 1968: see Vol. 7 p. 338.

Convention on Road Signs and Signals, 1968: see Vol. 7 p. 338. 


\section{SEA}

Convention on the Territorial Sea and the Contiguous Zone, 1958: see Vol. 6 p. 271. Convention on the High Seas, 1958: see Vol. 7 p. 339.

Convention on Fishing and Conservation of the Living Resources of the High Seas, 1958: see Vol. 6 p. 271.

Convention on the Continental Shelf, 1958: see Vol. 6 p. 271.

Optional Protocol of Signature concerning the Compulsory Settlement of Disputes, 1958: see Vol. 6 p. 272.

United Nations Convention on the Law of the Sea, 1982

(Continued from Vol. 9 p. 296)

State Sig. Cons.

Bangladesh 10 Dec $1982 \quad 27$ Jul 2001

Agreement relating to the Implementation of Part XI of the United Nations Convention on the Law of the Sea of 10 December 1982, 1994

(Continued from Vol. 8 p. 190, corrected from Vol. 9 p. 296)

\begin{tabular}{|c|c|c|c|c|c|c|}
\hline State & Sig. & Cons. & & State & Sig. & Cons. \\
\hline Bangladesh & 10 Dec 1982 & $27 \mathrm{Jul} 2001$ & 1 & Maldives & 10 Oct 1994 & $7 \mathrm{Sep} 2000$ \\
\hline
\end{tabular}

Agreement for the Implementation of the Provisions of the United Nations Convention on the Law of the Sea (...) relating to the Conservation and Management of Straddling Fish Stocks and Highly Migratory Fish Stocks, 1995

(Continued from Vol. 8 p. 191)

Entry into force: 11 December 2001

\section{SEA TRAFFIC AND TRANSPORT}

Convention Regarding the Measurement and Registration of Vessels employed in Inland Navigation, 1956: see Vol. 6 p. 273.

International Convention for the Safety of Life at Sea, 1960: see Vol. 6 p. 273.

International Convention on Load Lines, 1966: see Vol. 6 p. 274.

International Convention on Tonnage Measurement of Ships, 1969: see Vol. 6 p. 274.

Special Trade Passenger Ships Agreement, 1971, see Vol. 6 p. 275.

Protocol on Space Requirements for Special Trade Passenger Ships, 1973: see Vol. 6 p. 275.

Convention on a Code of Conduct for Liner Conferences, 1974: see Vol. 6 p. 276.

UN Convention on the Carriage of Goods by Sea, 1978: see Vol. 6 p. 276.

Protocol Relating to the International Convention for the Safety of Life at Sea, 1974 (as amended) 1978: see Vol. 6 p. 276. 


\section{Convention on Facilitation of International Maritime Traffic, 1965 as amended}

(Continued from Vol. 8 p. 191)

(Status as included in IMO doc. J/8687, as at 31 December 2003)

\begin{tabular}{|c|c|c|c|c|c|}
\hline State & Cons. & E.i.f. & State & Cons. & E.i.f. \\
\hline Indonesia & 4 Nov 2002 & & Korea (Rep) & 6 Mar 2001 & 5 May 2001 \\
\hline
\end{tabular}

Convention on the International Regulations for Preventing Collisions at Sea, 1972 as amended

(Continued from Vol. 6 p. 275)

Status as included in IMO doc. J/8687, as at 31 December 2003)

State Cons. E.i.f.

Mongolia 26 Jun $2002 \quad 26$ Jun 2002

International Convention for Safe Containers, as amended 1972

(Continued from Vol. 6 p. 275)

Status as included in IMO doc. J/8687, as at 31 December 2003)

State Cons. E.i.f.

Iran $\quad 11$ Oct $2001 \quad 11$ Oct 2001

International Convention for the Safety of Life at Sea, 1974, as amended (Continued from Vol. 6 p. 276)

Status as included in IMO doc. J/8687, as at 31 December 2003)

State Cons. E.i.f.

Mongolia 26 Jun $2002 \quad 26$ Sep 2002

Protocol Relating to the International Convention on Load Lines, 1988

(Continued from Vol. 8 p. 192)

Entry into force: 3 February 2000

(Status as included in IMO doc. J/8687, as at 31 December 2003)

\begin{tabular}{|c|c|c|c|c|c|}
\hline State & Cons. & E.i.f. & State & Cons. & E.i.f. \\
\hline Bangladesh & 18 Dec 2002 & & Pakistan & 25 Apr 2002 & $25 \mathrm{Jul} 2002$ \\
\hline Cambodia & 8 Jun 2001 & 8 Sep 2001 & Vietnam & 27 May 2002 & 27 Aug 2002 \\
\hline Korea (DPR) & 8 Aug 2001 & 8 Nov 2001 & & & \\
\hline
\end{tabular}

\section{SOCIAL MATTERS}

International Convention for the Suppression of the Circulation of and Traffic in Obscene Publications, 1923: see Vol. 6 p. 277. 
International Convention for the Suppression of the Traffic in Women and Children, 1921: see Vol. 6 p. 277.

Convention for the Suppression of the Circulation of, and Traffic in, Obscene Publications, 1923, amended by Protocol in 1947: see Vol. 6 p. 277.

International Convention for the Suppression of the Traffic in Women of Full Age, 1933: see Vol. 6 p. 277.

Convention for the Suppression of the Traffic in Women and Children, 1921, amended by Protocol in 1947, see Vol. 6 p. 277.

Convention for the Suppression of the Traffic in Women of Full Age, 1933, amended by Protocol, 1947: see Vol. 6 p. 277.

International Agreement for the Suppression of the White Slave Traffic, 1904, amended by Protocol 1949: see Vol. 6 p. 278.

International Convention for the Suppression of the White Slave Traffic, 1910, amended by Protocol 1949: see Vol. 6 p. 278.

Agreement for the Suppression of the Circulation of Obscene Publications, 1910, amended by Protocol 1949: see Vol. 6 p. 278.

Final Protocol to the Convention for the Suppression of the Traffic in Persons and of the Exploitation of the Prostitution of Others, 1950: see Vol. 6 p. 278.

\section{Convention for the Suppression of the Traffic in Persons and of the Exploitation of the Prostitution of Others, 1950 \\ (Continued from Vol. 7 p. 340)}

$\begin{array}{llllll}\text { State } & \text { Sig. } & \text { Cons } & \text { State } & \text { Sig. } & \text { Cons } \\ \text { Nepal } & \text { 10 Dec 2002 } & \text { Tajikistan } & \text { 19 Oct 2001 }\end{array}$

\section{TELECOMMUNICATIONS}

Constitution of the Asia-Pacific Telecommunity, 1976: see Vol. 8 p. 192.

Convention on the International Maritime Satellite Organization (INMARSAT), 1976 (as amended): see Vol. 8 p. 193.

Amendment to Article 11, Paragraph 2(a), of the Constitution of the Asia-Pacific Telecommunity, 1981: see Vol. 8 p. 193.

Amendments to articles 3(5) and 9(8) of the Constitution of the Asia-Pacific Telecommunity, 1991: see Vol. 9 p. 298

Agreement establishing the Asia-Pacific Institute for Broadcasting Development, 1977

(Continued from Vol. 9 p. 298)

State Sig. Cons

Cambodia $\quad 10$ Jul 2001 


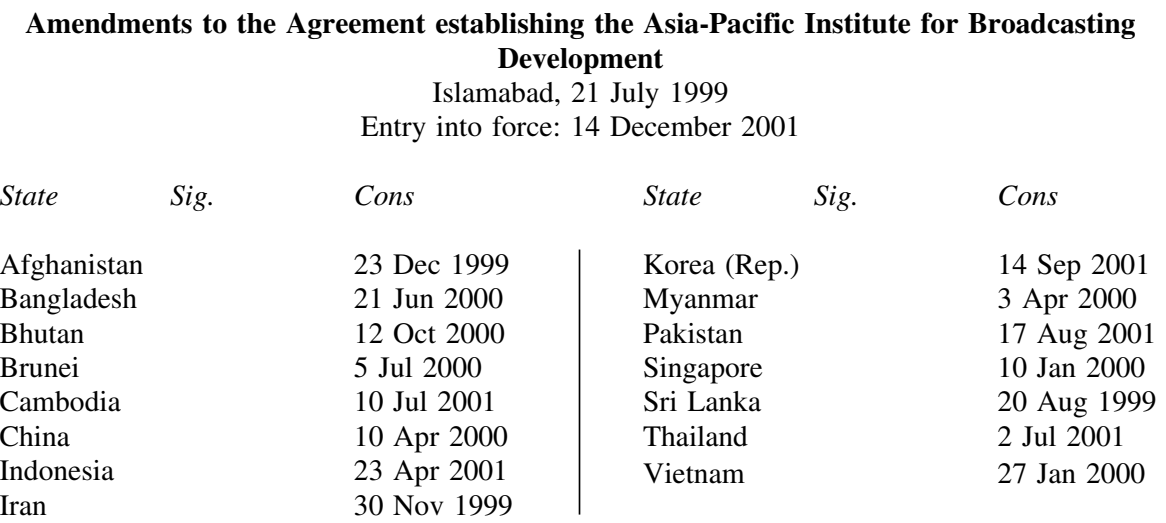

\section{TREATIES}

Vienna Convention on the Law of Treaties Between States and International Organizations or Between International Organizations, 1986: see Vol. 6 p. 280.

\section{Vienna Convention on the Law of Treaties, 1969}

(Continued from: Vol. 8 p. 193)

State Sig. Cons.

Vietnam 10 Oct 2001

\section{WEAPONS}

Protocol for the Prohibition of the Use in War of Asphyxiating, Poisonous or other Gases, and of Bacteriological Warfare, 1925: see Vol. 6 p. 281.

Treaty Banning Nuclear Weapon Tests in the Atmosphere, in Outer Space and Under Water, 1963: see Vol. 6 p. 281.

Treaty on the Prohibition of the Emplacement of Nuclear Weapons and Other Weapons of Mass Destruction on the Sea-Bed and the Ocean Floor and in the Subsoil Thereof, 1971: see Vol. 6 p. 282.

Convention on the Prohibition of the Development, Production and Stockpiling of Bacteriological (Biological) and Toxin Weapons and on Their Destruction, 1972: see Vol. 6 p. 282.

Convention on the Prohibition of Military or any other Hostile Use of Environmental Modification Techniques, 1976: see Vol. 8 p. 194. 
Treaty on the Non-Proliferation of Nuclear Weapons, 1968

(Continued and corrected from Vol. 6 p. 282, and dates included)

\begin{tabular}{|c|c|c|c|c|c|}
\hline State & Sig. & Cons. & State & Sig. & Cons. \\
\hline Afghanistan & $1 \mathrm{Jul} 1968$ & 4 Feb 1970 & Maldives & 11 Sep 1968 & 5 Mar 1970 \\
\hline Bangladesh & & 31 Aug 1979 & Mongolia & 1 Jul 1968 & 14 May 1969 \\
\hline Bhutan & & 23 May 1985 & Myanmar & & 2 Dec 1992 \\
\hline Brunei & & 26 Mar 1985 & Nepal & 1 Jul 1968 & 14 May 1969 \\
\hline Cambodia & & 2 Jun 1972 & Papua New & & \\
\hline China & & 9 Mar 1992 & Guinea & & 13 Jan 1982 \\
\hline Indonesia & 2 Mar 1970 & 12 Jul 1979 & Philippines & 7 Jan 1968 & 5 Oct 1972 \\
\hline Iran & 1 Jul 1968 & 2 Feb 1970 & Singapore & 5 Feb 1970 & 10 Mar 1976 \\
\hline Japan & 3 Feb 1970 & 8 Jun 1976 & Sri Lanka & $1 \mathrm{Jul} 1968$ & 5 Mar 1979 \\
\hline Kazakhstan & & 14 Feb 1994 & Tajikistan & & 17 Jan 1995 \\
\hline Korea (DPR) & & 12 Dec 1985 & Thailand & & $2 \operatorname{Dec} 1972$ \\
\hline Korea (Rep) & 1 Jul 1968 & 23 Apr 1975 & Turkmenistan & & 29 Sep 1994 \\
\hline Kyrgyzstan & & 5 Jul 1994 & Uzbekistan & & 2 May 1992 \\
\hline Laos & 1 Jul 1968 & 20 Feb 1970 & Vietnam & & 14 Jun 1982 \\
\hline Malaysia & 1 Jul 1968 & 20 Feb 1970 & & & \\
\hline
\end{tabular}

\section{Convention on Prohibitions or Restrictions on the Use of Certain Conventional Weapons which may be Deemed Excessively Injurious or to have Indiscriminate Effects, and Protocols, 1980 \\ (Continued from Vol. 9 p. 299)}

State Sig. Cons.

Korea (Rep.) 9 May 2001

Convention on the Prohibition of the Development, Production, Stockpiling and Use of Chemical Weapons and on Their Destruction, 1993

(Continued from Vol. 9 p. 299)

State Sig. Cons.

Thailand 14 Jan $1993 \quad 10$ Dec 2002

Comprehensive Nuclear Test Ban Treaty, 1996

(Continued from Vol. 8 p. 194)

\begin{tabular}{lll|lll} 
State & Sig. & Cons. & State & Sig. & Cons. \\
Kazakhstan & 30 Sep 1996 & 14 May 2002 & Singapore & 14 Jan 1999 & 10 Nov 2001 \\
Philippines & 24 Sep 1996 & 23 Feb 2001 & & &
\end{tabular}


Convention on the Prohibition of the Use, Stockpiling, Production and Transfer of Anti-Personnel Mines and on their Destruction, 1997

(Continued from Vol. 9 p. 300)

State Sig. Cons.

Afghanistan 11 Sep 2002 